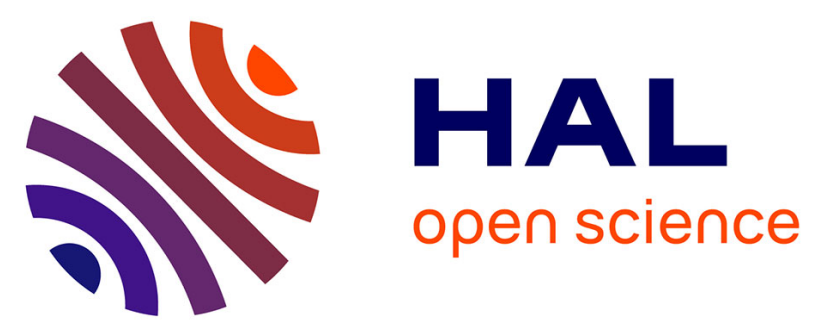

\title{
Histoplamosis in an immunocompetent man returning from Brazil: A diagnostic challenge helped by 18 FDG PET CT
}

Clémentine Montagnac, Carole Eldin, Anais Thouret, Stéphane Ranque, Philippe Brouqui

\section{To cite this version:}

Clémentine Montagnac, Carole Eldin, Anais Thouret, Stéphane Ranque, Philippe Brouqui. Histoplamosis in an immunocompetent man returning from Brazil: A diagnostic challenge helped by 18 FDG PET CT. Travel Medicine and Infectious Disease, 2019, 27, pp.136-138. 10.1016/j.tmaid.2018.10.004 . hal-02006693

\section{HAL Id: hal-02006693 \\ https://hal-amu.archives-ouvertes.fr/hal-02006693}

Submitted on 20 Mar 2019

HAL is a multi-disciplinary open access archive for the deposit and dissemination of scientific research documents, whether they are published or not. The documents may come from teaching and research institutions in France or abroad, or from public or private research centers.
L'archive ouverte pluridisciplinaire HAL, est destinée au dépôt et à la diffusion de documents scientifiques de niveau recherche, publiés ou non, émanant des établissements d'enseignement et de recherche français ou étrangers, des laboratoires publics ou privés. 


\title{
Histoplamosis in an immunocompetent man returning from Brazil: A diagnostic challenge helped by 18 FDG PET CT
}

\author{
Clémentine Montagnac ${ }^{\mathrm{a}}$, Carole Eldin ${ }^{\mathrm{a}, *}$, Anais Thouret $^{\mathrm{a}}$, Stéphane Ranque ${ }^{\mathrm{a}}$, Philippe Brouqui ${ }^{\mathrm{b}}$ \\ a Aix Marseille Univ, IRD, AP-HM, SSA, VITROME, IHU-Méditerranée Infection, Marseille, France \\ ${ }^{\mathrm{b}}$ Aix Marseille Univ, IRD, AP-HM, MEPHI, IHU-Méditerranée Infection, Marseille, France
}

A R T I C L E I N F O

\section{Keywords:}

Histoplasma capsulatum

Brazil

Travel

Immunocompetent

A 43-year-old French man presented with fever, arthralgia, headache, night sweats and dry cough, 3 weeks after returning from Brazil. Physical examination was normal. He reported a visit at the botanic garden of Rio de Janeiro during a 7-day-trip. Blood tests revealed lymphocytosis $(5.28 \mathrm{G} / \mathrm{L})$, C-reactive protein at $50 \mathrm{mg} / \mathrm{L}$, and cholestatic hepatitis (ASAT 148UI/L, ALAT 319UI/L, gamma-GT: 523UI/L, alkaline phosphatase: $234 \mathrm{UI} / \mathrm{L}$ ). Microbiological investigations were negative for the following: blood cultures, malaria quick test, Legionella pneumophila, Streptococcus pneumonia antigenuria; serology for HIV, Histoplasma, Brucella, Leptospira, blood PCR for C. burnetii, Histoplasma, Leptospira, culture and PCR for Mycobacterium tuberculosis. Chest CTScan showed bilateral lower lobes pulmonary condensations, two upper left supracentimetric nodules, a right hilar lymphadenopathy and a minimal bilateral pleural effusion.

Because of no improvement after 2 weeks, malignancy was suspected, and 18-FDG-PET-CT was performed (Fig. 1a) showing intense FDG uptake affecting mediastinal and hilar lymph nodes, pulmonary nodules, hepatic hilar lymph nodes, spleen, and bone marrow. A bronchoalveolar lavage and transbronchic lymph node aspiration were performed. The lymph node showed a lymphocytosis and a positive Histoplasma capsulatum-specific PCR. Culture on Sabouraud chloramphenicol gentamicin agar yielded one fluffy white colony identified as $H$. capsulatum via both MALDI-TOF and ITS2 rRNA region sequencing. The patient condition improved under itraconazole. After a 12week treatment, 18-FDG-PET-CT (Fig. 1b) showed a complete regression of pathologic uptake.

$H$. capsulatum (a dimorphic fungus) is endemic in America, spread by droppings of birds of bats. It is transmitted to humans by the inhalation of contaminated spores. It induces disseminated infection in immunocompromised hosts and is symptomatic in $10 \%$ of cases in immunocompetent patients. In this report where malignancy was suspected, 18-FDG-PET-CT helped guiding the diagnosis. Clinicians in Europe should consider histoplamosis in the differential diagnosis of hypermetabolic lymphadenopathy or lung nodules in immunocompetent travelers returning from endemic countries.

\footnotetext{
* Corresponding author. VITROME, Institut Hospitalo-Universitaire Méditerranée Infection, 19-21 Boulevard Jean Moulin, 13385, Marseille Cedex 05, France.

E-mail address: carole.eldin@ap-hm.fr (C. Eldin).
} 

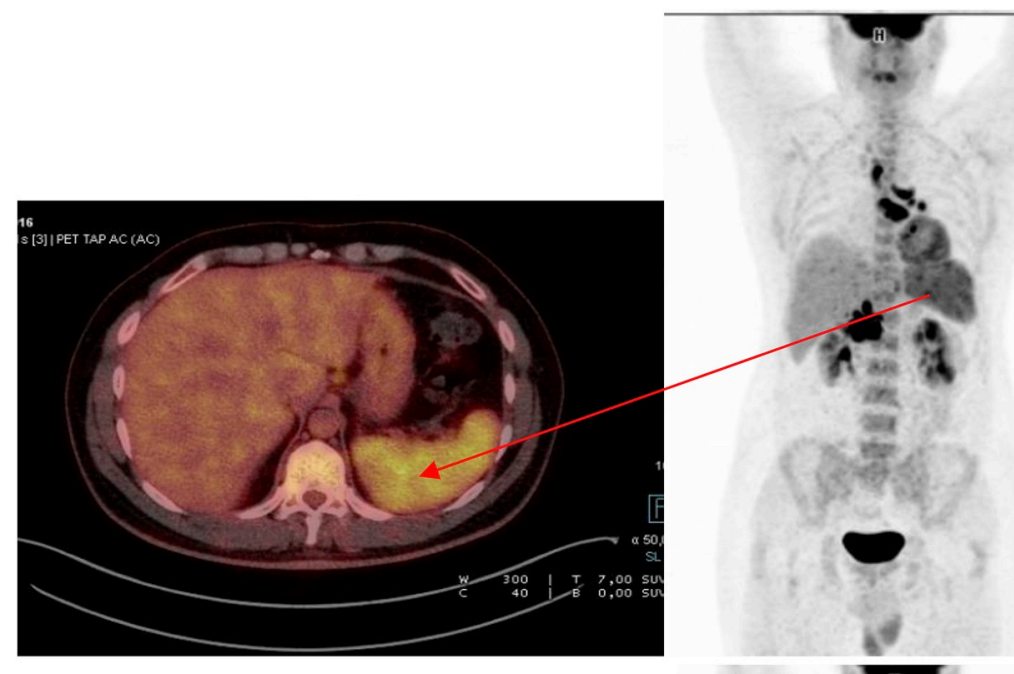

A
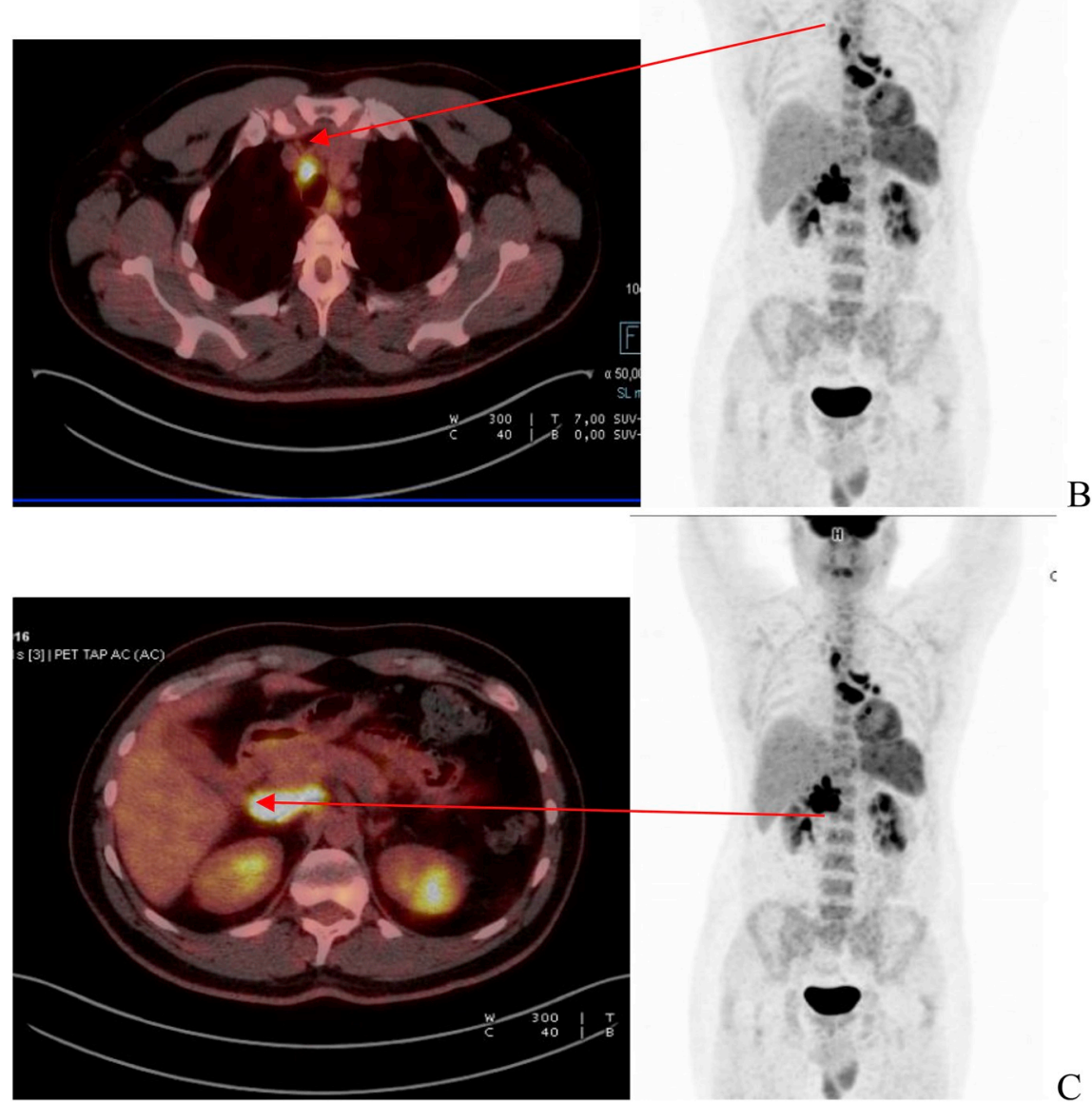

Fig. 1. Legend

$1 \mathrm{a}$

18F FDG PET CT scan at diagnosis.

A. Intense splenic FDG uptake

B. Intense mediastinal lymph node uptake

C. Intense hilar hepatic lymph node uptake

$1 \mathrm{~b}$

18F FDG PET CT scan after treatment

A. Regression of splenic uptake

B. Regression of mediastinal uptake

C. Regression of hilar hepatic lymph node uptake. 


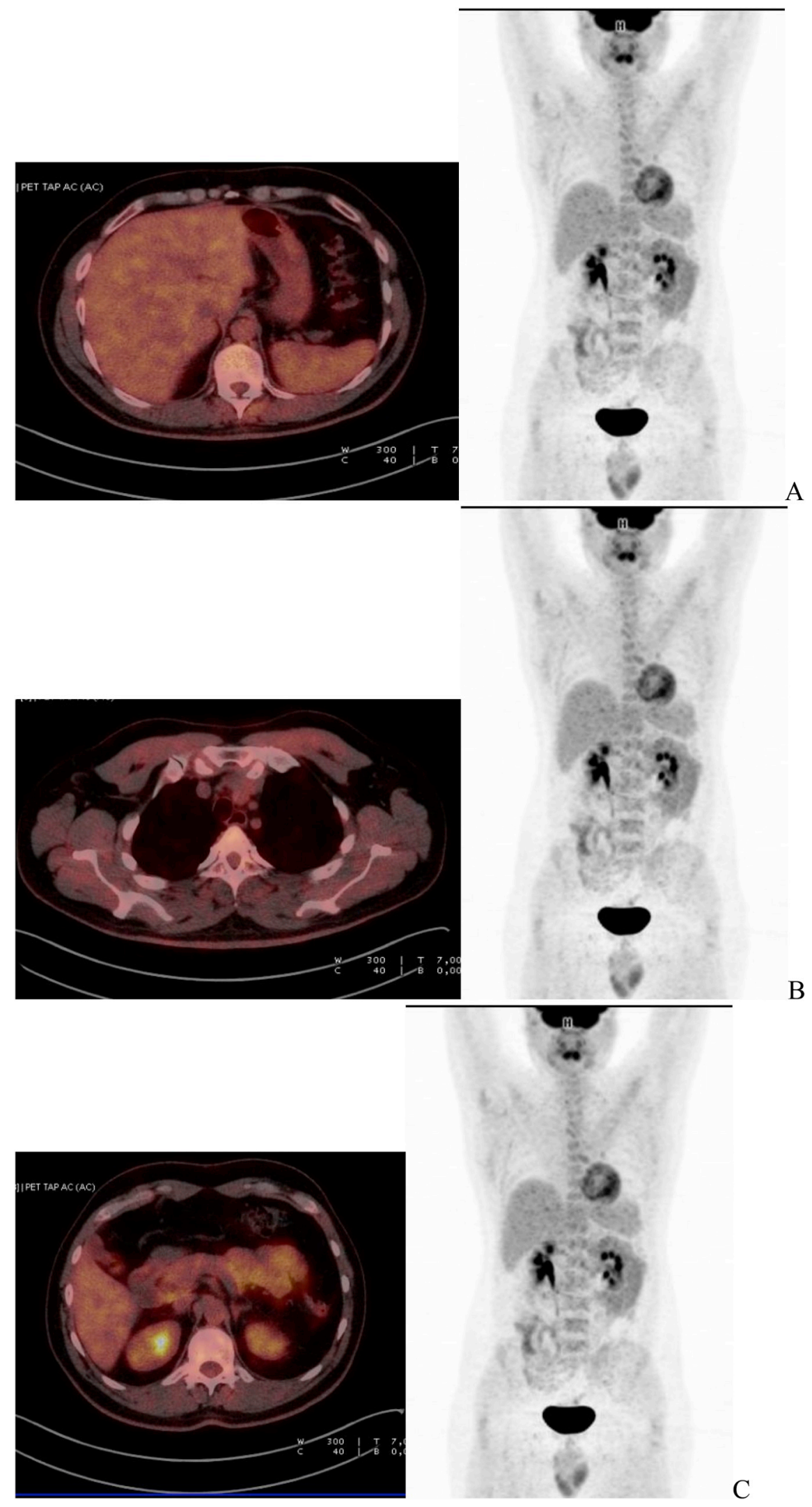

Fig. 1. (continued)

\section{Acknowledgments}

This work was supported by the French Government under the « Investissements d'avenir » (Investments for the Future) program managed by the Agence Nationale de la Recherche (ANR, fr: National Agency for Research), (reference: Méditerranée Infection 10-IAHU-03). The funders had no role in study design, data collection and analysis, decision to publish, or preparation of the manuscript. 